\title{
PENGARUH MODEL PEMBELAJARAN DISCOVERY LEARNING TERHADAP KEMAMPUAN PEMAHAMAN KONSEP MATEMATIS SISWA KELAS IX SMP NEGERI 5 SUMBUL
}

\author{
Verawaty Sihotang \\ Universitas Katolik Santo Thomas, Medan; \\ verawatysihouthank@gmail.com
}

\begin{abstract}
Abstrak. Penelitian ini bertujuan untuk mengetahui kemampuan pemahaman konsep matematis siswa yang mengikuti pembelajaran dengan model pembelajaran Discovery Learning lebih tinggi dari pada kemampuan pemahaman konsep matematis siswa yang mengikuti pembelajaran konvensional dan respon siswa terhadap model pembelajaran Discovery Learning. Penelitian ini dilakukan di SMP Negeri 5 Sumbul pada Tahun Pelajaran 2017/2018. Sampel dalam penelitian ini adalah kelas IX-1 sebagai kelas eksperimen sebanyak 35 orang dan kelas IX-2 sebagai kelas kontrol sebanyak 35 orang. Metode penelitian yang digunakan adalah metode eksperimen kuasi dengan desain pretestpostest control group design. Hasil uji hipotesis menunjukkan pada taraf signifikansi $\propto=0,05$ nilai thitung $=4,964>$ tabel $=1,667$. Sehingga $\mathrm{H}_{0}$ ditolak dan $\mathrm{H}_{a}$ diterima, yang berarti bahwa kemampuan pemahaman konsep matematis siswa yang mengikuti pembelajaran dengan model pembelajaran Discovery Learning lebih tinggi dibandingkan dengan kemampuan pemahaman siswa yang mengikuti pembelajaran konvensional. Hasil analisis angket respon siswa terhadap model pembelajaran Discovery Learning diperoleh: (1) 98,57\% siswa tertarik; (2) 96,67\% siswa menyatakan ada manfaat yang didapatkan; (3) 75\% siswa menyatakan tidak ada kendala yang dialami selama proses pembelajaran; dan (4) $84,76 \%$ siswa berharap bahwa model pembelajaran Discovery Learning digunakan dalam proses pembelajaran. Hal ini menunjukkan bahwa respon siswa positif terhadap model pembelajaran Discovery Lerning.
\end{abstract}

Kata Kunci. Discovery learning, kemampuan pemahaman konsep matematis

Abstract. This study aims to determine the ability to understand the mathematical concepts of students who take part in learning with the discovery learning model higher than the ability to understand the mathematical concepts

Cartesius: Jurnal Pendidikan Matematika Vol. 1, No. 1

CProdi Pendidikan Matematika Universitas Katolik Santo Thomas 
of students who follow conventional learning and student responses to the discovery learning model. This research was conducted at 5 Sumbul Junior High School in 2017/2018 Academic Year. The sample in this study was class IX-1 as an experimental class as many as 35 people and class IX-2 as a control class of 35 people. The research method used was the quasi-experimental method with the design of pretest-posttest control in group design. Hypothesis test results show at the significance level $=0.05$ the value of $t$ count $=4.964>t$ table $=1.667$. So that HO is rejected and Ha is accepted, which means that the ability to understand the mathematical concepts of students who take part in learning with the discovery learning model is higher than the comprehension abilities of students who take conventional learning. The results of the questionnaire analysis of student responses to the discovery learning model were obtained: (1) $98.57 \%$ of students were interested; (2) $96.67 \%$ of students stated that there were benefits obtained; (3) $75 \%$ of students stated that there were no obstacles experienced during the learning process; and (4) $84.76 \%$ of students hope that the discovery learning model is used in the learning process. This shows that the positive student response to the discovery learning model.

Keywords. Discovery learning, mathematical concept understanding ability

\section{PENDAHULUAN}

Perkembangan teknologi dan informasi yang cepat berubah saat ini membutuhkan manusia yang siap dan tanggap. Salah satu cara untuk menghasilkan manusia yang dimaksud adalah melalui pendidikan. Pendidikan merupakan suatu kebutuhan yang sangat penting dan perlu dipersiapkan dalam membentuk generasi penerus bangsa dan mengantisipasi perkembangan ilmu pengetahuan dan teknologi yang semakin berkembang pesat dan juga dapat menjadi bekal kehidupan di masa yang akan datang. [1].

Kualitas pendidikan tercermin dalam proses pembelajaran di sekolah sebagai lembaga pendidikan formal. Salah satu mata pelajaran yang disajikan dalam pendidikan formal adalah matematika. Matematika memiliki peranan penting dalam pendidikan. Oleh karena itu matematika ditetapkan sebagai salah satu mata pelajaran wajib dalam setiap Ujian Akhir Nasional (UAN) dan beban belajarnya lebih banyak daripada mata pelajaran lain [2]. Walaupun matematika itu penting dan mempunyai peranan dalam kehidupan namun itu tidak didukung dengan fakta yang terjadi di lapangan.

Cartesius: Jurnal Pendidikan Matematika Vol. 1, No. 1

CProdi Pendidikan Matematika Universitas Katolik Santo Thomas 
Tetap saja prestasi belajar matematika siswa sekolah menengah khususnya di Indonesia masih tergolong rendah [3]. Menurut pandangan yang berkembang selama ini, siswa merasa tidak peduli akan pentingnya matematika dalam kehidupannya karena sebagian besar siswa menganggap matematika sebagai momok yang menakutkan bahkan menyebabkan siswa malas mempelajarinya bahkan menghindari pelajaran tersebut. Selain itu juga tidak jarang siswa mengeluh karena dianggap mata pelajaran matematika membuat siswa pusing. [4]. Menanggapi permasalahanpermasalahan yang ada, diperlukan upaya serius dan maksimal dari guru.

Keberhasilan penguasaan konsep awal matematika pada siswa menjadi pembuka jalan dalam penyampaian konsep-konsep matematika selanjutnya sehingga siswa akan lebih mudah memahami konsep-konsep dalam matematika pada materi-materi selanjutnya. Selain itu, jika siswa menguasai konsep dengan baik maka siswa dapat menyelesaikan berbagai variasi soal matematika dan dapat mempermudah siswa dalam menyelesaikan masalah matematika yang berkaitan dengan kehidupan sehari- hari. Karena konsepkonsep dalam matematika memiliki keterkaitan antara satu dengan yang lainnya, maka siswa harus lebih banyak diberikan kesempatan untuk melihat kaitan-kaitan dengan materi yang lain. Hal tersebut dimaksudkan agar siswa dapat memahami materi matematika secara mendalam.

Mengenai pentingnya pemahaman konsep matematika terlihat dalam salah satu tujuan pembelajaran matematika berdasarkan Permendiknas Nomor 22 Tahun 2006 tentang standar isi yaitu memahami konsep matematika, menjelaskan keterkaitan antar konsep dan mengaplikasikan konsep atau algoritma secara luwes, akurat, efisien dan tepat dalam pemecahan masalah [5]. Pemahaman terhadap suatu konsep sangat penting karena apabila siswa menguasai konsep materi prasyarat maka siswa akan mudah untuk memahami konsep materi berikutnya. Bahkan kemampuan pemahaman konsep dalam matematika diperlukan karena konsep-konsep dalam matematika saling berhubungan dan berkesinambungan [6].

Kemampuan pemahaman konsep matematis siswa mempengaruhi hasil belajar. Mulyono menyatakan pengertian hasil belajar sebagai tolak ukur Cartesius: Jurnal Pendidikan Matematika Vol. 1, No. 1

CProdi Pendidikan Matematika Universitas Katolik Santo Thomas 
kemampuan yang diraih seseorang yang dinyatakan dalam bentuk angka setelah melakukan suatu kegiatan belajar [7]. Berdasarkan hasil Programme for International Student Assessment (PISA) 2012, dapat diketahui bahwa Indonesia berada diperingkat ke-64 dari 65 negara yang berpartisipasi dalam tes. Penilaian itu dipublikasikan The Organization for Economic Cooperation and Development (OECD) yang menyatakan bahwa rata-rata skor matematika anak-anak Indonesia 375, rata-rata skor membaca 396, dan rata-rata skor untuk sains 382. Padahal rata-rata skor OECD secara berurutan adalah 494, 496, dan 501 [8].

Permasalahan tentang rendahnya hasil belajar terkait pemahamanan konsep matematis siswa juga ditemukan di SMP Negeri 5 Sumbul. Berdasarkan hasil wawancara yang dilakukan peneliti dengan salah satu guru matematika di SMP Negeri 5 Sumbul tepatnya guru matematika yang mengajar di kelas IX menjelaskan bahwa pemahaman konsep matematis siswa masih rendah. Hal ini terbukti dengan siswa yang masih kesulitan dalam mengerjakan soal yang berbeda dari contoh yang diberikan. Faktor lain ialah kurangnya respon siswa terhadap pembelajaran matematika dan siswa lebih cenderung menghafal dari pada memahami konsep sehingga menyebabkan siswa kurang terlatih mengembangkan keterampilan berpikir dalam memecahkan masalah dan menerapkan konsep-konsep yang telah dipelajari ke dalam suatu permasalahan. Peran siswa dalam proses pembelajaran masih kurang, yakni hanya sedikit siswa yang menunjukkan keaktifan berpendapat dan bertanya. Hal ini menunjukkan bahwa masih banyaknya siswa yang cenderung hanya berfokus kepada guru saja.

Selanjutnya, berdasarkan hasil latihan siswa yang dilakukan oleh peneliti dengan memberikan mini test tentang soal pemahaman konsep matematika dengan materi yang telah dipelajari atau materi prasyarat (konsep sudut, perbandingan, dan konsep bangun datar) yang di ujikan pada kelas VIII 1 yang berjumlah 33 orang dari jumlah keseluruhan siswa kelas VIII sebanyak 70 orang, menunjukkan bahwa hasil rata-rata nilai mini test tersebut masih rendah dengan rata-rata nilainya sebesar 29,56 dan ini belum memuaskan karena tidak memenuhi standar Kriteria Ketuntasan Minimal (KKM) yaitu 70. Hampir keseluruhan siswa kelas VIII 1 tersebut tidak bisa menjawab soal 
dengan baik. Salah satu contoh lembar jawaban siswa kelas VIII 1 SMP Negeri 5 Sumbul seperti di bawah ini:

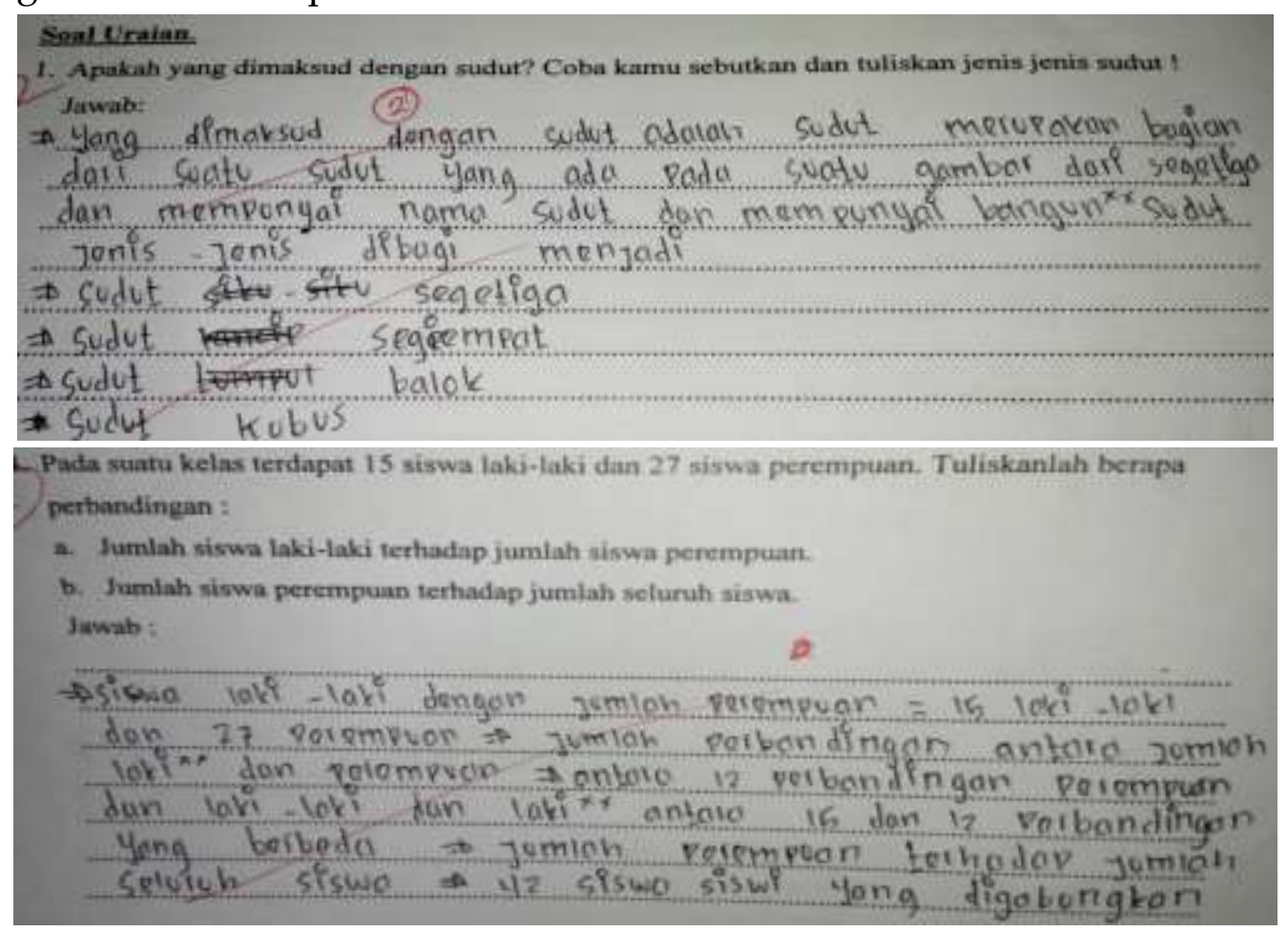

Gambar 1. Hasil Penyelesaian Siswa yang Berhubungan dengan Soal Kemampuan Pemahaman Konsep Matematis

Hal ini menunjukkan bahwa kemampuan pemahaman konsep siswa kelas VIII SMP Negeri 5 tersebut masih belum maksimal atau dengan kata lain dapat dinyatakan masih rendah. Rendahnya pemahaman konsep matematis siswa salah satunya dipengaruhi oleh kemampuan guru dalam memilih dan menerapkan model pembelajaran di kelas. Pola interaksi pembelajaran yang biasanya hanya berpusat pada guru seharusnya diubah menjadi pola interaksi pembelajaran yang berpusat pada siswa dengan tujuan agar siswa terlibat aktif dalam proses pembelajaran.

Keberhasilan siswa dalam belajar sangat tergantung dari metode atau cara guru mengajar. Oleh karena itu metode diperlukan guru dalam kegiatan belajar mengajar dan berharap penerapannya bervariasi sesuai dengan tujuan yang hendak dicapai [9]. Belajar yang efisien dapat tercapai apabila guru dapat menggunakan strategi belajar yang tepat. Oleh karena itu guru dituntut untuk profesional dalam menjalankan tugasnya. Guru yang 
profesional adalah guru yang selalu berpikir akan dibawa ke mana anak didiknya, serta dengan apa mengarahkan anak didiknya untuk mencapai hasil yang diinginkan dengan berbagai inovasi pembelajaran.

Salah satu yang menjadi visi pendidikan matematika dalam pembelajaran matematika adalah penguasaan konsep dalam menyelesaikan masalahmasalah [10]. Salah satu alternatif tindakan yang dapat dilakukan adalah dengan menerapkan model Discovery Learning. Model Discovery Learning merupakan model pembelajaran yang dikembangkan atas dasar teori siswa akan lebih banyak belajar sendiri dan mengembangkan kreativitas. Siswa betul-betul ditempatkan sebagai subjek belajar karena kegiatan belajar berpusat pada siswa (student learning). Hal tersebut sesuai dengan pernyatan Illahi bahwa salah satu model yang memungkinkan siswa terlibat langsung dalam kegiatan belajar mengajar, yang berkaitan dengan proses mentalnya dalam menemukan suatu konsep atau teori yang sedang dipelajari adalah discovery learning. Dengan adanya model pembelajaran discovery learning siswa merupakan bagian dari keaktifan siswa dalam mengikuti kegiatan belajar-mengajar di kelas dan membantu siswa membentuk cara kerja bersama yang efektif, saling membagi informasi, serta mendengar dan menggunakan ide-ide orang lain [11].

Dalam menemukan konsep, siswa melakukan pengamatan, menggolongkan, membuat dugaan, menjelaskan, menarik kesimpulan dan sebagainya untuk menemukan beberapa konsep atau prinsip. Artinya model ini dapat membuat siswa berfikir kreatif dan mandiri karena diajak untuk menemukan dan mencari tahu sendiri rumus atau konsep yang akan dipelajari. Model pembelajaran Discovery Learning ini sesuai dengan tujuan kurikulum 2013 yang menyarankan agar peserta didik belajar secara aktif dan mandiri dalam kegiatan pembelajaran.

Model pembelajaran Discovery Learning baik untuk diterapkan dalam pembelajaran matematika. Hal ini dibuktikan dengan adanya hasil penelitian yang dilakukan oleh Haryanti Fhina dan Bagus A. S (2016) tentang pengembangan modul matematika berbasis discovery learning berbantuan flipbook maker untuk meningkatkan kemampuan pemahaman konsep pada 
materi segitiga menunjukkan hasil bahwa rata-rata hasil belajar siswa yang menggunakan modul matematika berbasis discovery learning berbantuan flipbook maker pada materi segitiga lebih baik daripada rata-rata hasil belajar siswa yang tidak menggunakan modul matematika berbasis discovery learning berbantuan flipbook maker. Sehingga modul tersebut efektif untuk meningkatkan kemampuan pemahaman konsep siswa khusus pada materi segitiga [12].

Berdasarkan uraian di atas dianggap perlu meneliti pengaruh model pembelajaran Discovery Learning terhadap kemampuan pemahaman konsep matematis siswa kelas IX SMP Negeri 5 Sumbul.

\section{METODE}

Penelitian ini merupakan penelitian yang menggunakan pendekatan kuantitatif dan kualitatif dengan metode penelitian eksperimen kuasi. Penelitian ini dilaksanakan di SMP Negeri 5 Sumbul. Penelitian ini dilaksanakan pada siswa kelas IX semester ganjil tahun ajaran 2017/2018. Desain penelitian yang digunakan peneliti adalah Pretest-Posttest Control Group Design yang disajikan sebagai berikut:

Tabel 1. Pretest-Posttest Control Group Design

\begin{tabular}{cccc}
\hline Kelas & Pretest & Perlakuan & Posttest \\
\hline $\mathrm{E}$ & $\mathrm{O}_{1}$ & $\mathrm{X}$ & $\mathrm{O}_{2}$ \\
$\mathrm{~K}$ & $\mathrm{O}_{3}$ & - & $\mathrm{O}_{4}$ \\
\hline
\end{tabular}

(Sumber: Setyosari, 2012: 180)

Keterangan:

$X$ : Perlakuan model pembelajaran Discovery Learning di kelas eksperimen

$\mathrm{O}_{1}$ : Pretest kelas eksperimen

$\mathrm{O}_{2}$ : Posttest kelas eksperimen

$\mathrm{O}_{3}$ : Pretest kelas control

O4: Posttest kelas kontrol

Dalam hal ini peneliti menggunakan tes mengenai materi prasyarat dari materi kesebangunan pada siswa sebagai tes awal (pretest) yaitu sebelum menggunakan model pembelajaran Discovery Learning dan memberikan tes Cartesius: Jurnal Pendidikan Matematika Vol. 1, No. 1

CProdi Pendidikan Matematika Universitas Katolik Santo Thomas 
mengenai materi kesebangunan sesudah menggunakan model pembelajaran Discovery Learning sebagai tes akhir (posttest). Adapun rancangan penelitian yang akan dilaksanakan dapat dilihat pada gambar berikut ini:

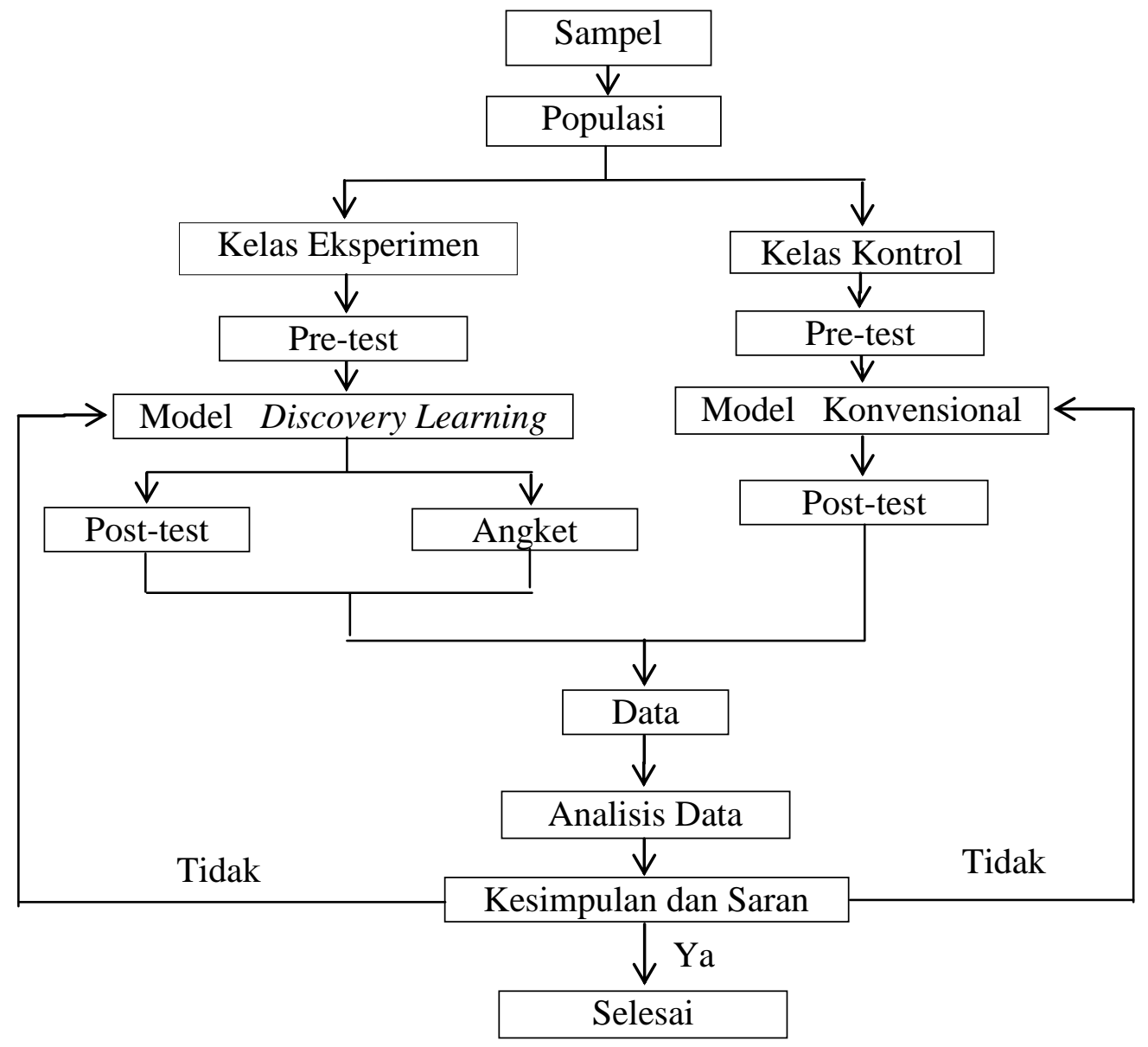

Gambar 2. Rancangan Penelitian

Populasi penelitian ini adalah seluruh kelas IX SMP Negeri 5 Sumbul tahun ajaran 2017/2018 yang terdiri dari dua kelas yaitu kelas IX-1 dan IX-2 dengan masing-masing kelas terdiri dari 35 orang siswa. Teknik pengambilan sampel dalam penelitian ini menggunakan teknik acak atau simple random sampling. Jadi sampel dalam penelitian ini adalah seluruh siswa kelas IX-1 sebagai kelas eksperimen dan seluruh siswa kelas IX-2 sebagai kelas kontrol.

Teknik pengumpulan data yang digunakan adalah teknik tes dan non tes. Teknik tes yang dimaksud adalah tes kemampuan pemahaman konsep dan teknik non tes berupa angket untuk mengetahui respon siswa terhadap model pembelajaran yang diterapkan. Teknik tes meliputi tes kemampuan 
pemahaman konsep matematis untuk materi prasyarat (pretest) dan materi posttest yang terdiri dari 5 soal berbentuk uraian. Dipilih tes berbentuk uraian karena dengan tes berbentuk uraian dapat diketahui proses pengerjaan siswa dalam menyelesaikan soal matematika. Dengan demikian diharapkan dapat dengan tepat diidentifikasi tingkat kemampuan pemahaman konsep matematis yang dicapai siswa. Kemampuan pemahaman konsep yang dapat diukur dari soal-soal yang diberikan meliputi: 1) Menyatakan ulang sebuah konsep; 2) Mengklasifikasikan objekobjek menurut sifat-sifat tertentu; 3) Memberi contoh dan non contoh dari konsep; 4) Menyajikan konsep dalam berbagai bentuk representasi matematis; 5) Mengaplikasikan konsep atau algoritma dalam pemecahan masalah.

Teknik non tes yang dimaksud dalam penelitian ini yaitu menggunakan angket. Angket tentang respon siswa dalam penelitian ini bertujuan untuk mengetahui tanggapan siswa terhadap kegiatan pembelajaran matematika dengan menggunakan model Discovery Learning. Pernyataan-pernyataan pada angket respon siswa berupa pernyataan positif dan negatif berkenaan dengan aspek yang akan diukur yang disusun dalam bentuk skala Likert.

Hasil angket respon siswa dianalisis dengan persentase dari setiap jawaban siswa, dengan menggunakan rumus yang dimodifikasi dari Arifin (dalam Purwanto, dkk, 2015: 133) sebagai berikut:

$$
\mathrm{P}=\frac{\sum K}{\sum N} \times 100 \%
$$

Keterangan: $\mathrm{P}=$ Persentase respon siswa

$\mathrm{K}=$ Jumlah siswa yang memilih option

$\mathrm{N}=$ Jumlah siswa/responden

Adapun kriteria respon siswa yang dimodifikasi dari Khabibah dapat dilihat pada tabel seperti berikut:

Tabel 2. Kriteria Respon Siswa

\begin{tabular}{ccc}
\hline No & Persentase Respon Siswa $(\%)$ & Kategori \\
\hline 1 & $\mathrm{RS} \geq 85 \%$ & Sangat Positif \\
2 & $70 \% \leq \mathrm{RS}<85 \%$ & Positif
\end{tabular}

Cartesius: Jurnal Pendidikan Matematika Vol. 1, No. 1

CProdi Pendidikan Matematika Universitas Katolik Santo Thomas 


\section{HASIL DAN PEMBAHASAN}

Dalam penelitian ini digunakan model pembelajaran Discovery Learning pada kelas IX-1 sebagai kelas eksperimen, sedangkan pada kelas IX-2 sebagai kelas kontrol diterapkan pembelajaran konvensional. Berdasarkan hasil penelitian di atas diketahui bahwa nilai rata-rata kelas eksperimen sebesar 81,86 sedangkan kelas kontrol sebesar 67,43.

Hal tersebut juga didukung dengan hasil uji hipotesis yang menggunakan uji-t yang menunjukkan nilai thitung $=5,009>1,667(\mathrm{t}(68 ; 0,05))$, maka $\mathrm{H}_{a}$ diterima dan $\mathrm{H}_{0}$ ditolak. Selain itu, nilai rata-rata keamampuan pemahaman konsep matematis siswa kelas eksperimen yang mengikuti model pembelajaran Discovery Learning adalah sebesar 81,86, sedangkan nilai rata-rata kemampuan pemahaman konsep matematis siswa kelas kontrol yang mengikuti pembelajaran konvensional adalah sebesar 67,43. Hal ini menunjukkan bahwa nilai kemampuan pemahaman konsep matematis siswa kelas eksperimen lebih tinggi dibandingkan kemampuan pemahaman konsep matematis siswa kelas kontrol. Dengan kata lain model pembelajaran Discovery Learning berpengaruh terhadap kemampuan pemahaman konsep matematis siswa.

Dengan pembelajaran menggunakan model Discovery Learning ini, siswa dituntut untuk dapat menemukan sendiri hal-hal yang mereka belum ketahui sebelumnya dengan cara berdiskusi dengan sesama teman kelompoknya, yang mengakibatkan mereka lebih bebas dalam mengeluarkan pendapat. Sementara pada kelas kontrol, pembelajaran didominasi oleh guru dan menggunakan pendekatan ekpositori dalam pembelajaran. Pada kelas eksperimen, tiap kelompok terdiri dari 5 orang dan kegiatan diskusi serta bahan belajar terpenuhi. Hasil yang diperoleh dalam penelitian ini menunjukkan bahwa pembelajaran matematika dengan model Discovery Learning dapat meningkatkan kemampuan pemahaman konsep matematis siswa. Hasil analisis angket respon siswa terhadap model pembelajaran Discovery Learning juga menunjukkan bahwa respon siswa 
cenderung positif, yang mana dalam hal ini berarti siswa merasa senang dan suka belajar menggunakan model pembelajaran Discovery Learning.

Berdasarkan pembahasan hasil penelitian dan uraian dari beberapa pernyataan dapat disimpulkan bahwa, kemampuan pemahaman konsep matematis siswa pada kelas eksperimen lebih timggi dibandingkan dengan kelas kontrol, selain itu siswa pada kelas eksperimen merespon dengan baik terhadap pembelajaran yang menggunakan model Discovery Learning. Dengan demikian terbukti bahwa model pembelajaran Discovery Learning berpengaruh terhadap kemampuan pemahaman konsep matematis siswa.

Hasil respon siswa diperoleh: (1) Sebesar 98,57\% siswa tertarik terhadap model pembelajaran Discovery Learning. (2) Sebesar 96,67\% siswa menyatakan ada manfaat yang didapatkan dengan menggunakan model pembelajaran Discovery Learning. (3) Sebesar 75\% siswa menyatakan tidak ada kendala yang dialami selama proses pembelajaran menggunakan model pembelajaran Discovery Learning. (4) Sebesar 84,76\% siswa berharap bahwa model pembelajaran Discovery Learning digunakan dalam proses pembelajaran. Berdasarkan data tersebut, respon siswa positif terhadap model pembelajaran Discovery Learning.

\section{KESIMPULAN}

Berdasarkan hasil penelitian yang dilaksanakan mengenai pembelajaran matematika dengan model pembelajaran Discovery Learning terhadap kemampuan pemahaman konsep matematis siswa kelas IX SMP Negeri 5 Sumbul, diperoleh beberapa kesimpulan sebagai berikut:

1. Kemampuan pemahaman konsep matematis siswa pada kelas ekperimen memiliki nilai rata-rata 81,86 sedangkan kemampuan pemahaman konsep matematis siswa pada kelas kontrol sebesar 67,43. Hal ini menunjukkan bahwa nilai rata-rata kelas eksperimen lebih tinggi dari pada nilai ratarata kelas kontrol dengan jumlah selisih sebesar 14,43. Selanjutnya diperoleh juga hasil pengujian hipotesis dimana thitung lebih besar dari tabel yaitu 5,009 > 1,667 dengan taraf signifikansi 5\% sehingga $\mathrm{H}_{0}$ ditolak dan $\mathrm{H}_{\mathrm{a}}$ diterima. Hal ini berarti kemampuan pemahaman konsep matematis siswa yang yang mengikuti model pembelajaran discovery learning lebih

Cartesius: Jurnal Pendidikan Matematika Vol. 1, No. 1

CProdi Pendidikan Matematika Universitas Katolik Santo Thomas 
tinggi dari pada siswa yang mengikuti pembelajaran konvensional, dengan kata lain model pembelajaran discovery learning berpengaruh terhadap kemampuan pemahaman konsep matematis siswa.

2. Hasil respon siswa diperoleh: (1) Sebesar 98,57\% siswa tertarik terhadap model pembelajaran Discovery Learning. (2) Sebesar 96,67\% siswa menyatakan ada manfaat yang didapatkan dengan menggunakan model pembelajaran Discovery Learning. (3) Sebesar 75\% siswa menyatakan tidak ada kendala yang dialami selama proses pembelajaran menggunakan model pembelajaran Discovery Learning. (4) Sebesar 84,76\% siswa berharap bahwa model pembelajaran Discovery Learning digunakan dalam proses pembelajaran. Berdasarkan data tersebut, respon siswa positif terhadap model pembelajaran Discovery Learning.

\section{UCAPAN TERIMAKASIH}

Penulis menyampaikan terimakasih kepada Ibu Tetty Natalia Sipayung, S.Si., M.Pd. sebagai dosen pembimbing 1 dan Ibu Sinta Dameria Simanjuntak, S.Si., M.Pd. sebagai dosen pembimbing 2 yang telah mengarahkan dan membimbing penulis mulai dari awal penelitian hingga berakhirnya penelitian sehingga penulis dapat menuliskan artikel ini yang merupakan bagian dari hasil penelitian penulis. Penulis juga menyampaikan terimakasih kepada kepala program studi Pendidikan Matematika, dekan, dan rektor Universitas Katolik Santo Thomas atas dukungan yang diberikan kepada penulis.

\section{DAFTAR PUSTAKA}

[1] A. C. Fitria, D. Sulistyaningsih, M. Prihaswati, A. Alam, U. M. Semarang, and U. M. Semarang, "Keefektifan Metode Guideddiscovery Learning Bernuansa Multiple Intelligences Untuk Meningkatkan Kemampuan," vol. 1, no. September, 2014.

[2] R. Fitri, H. Syarifuddin, and S. Pengajar Jurusan, "Penerapan Strategi the Firing Line Pada Pembelajaran Matematika Siswa Kelas Xi Ips Sma Negeri 1 Batipuh," J. Pendidik. Mat. Part, vol. 3, no. 1, pp. 18-22, 2014.

[3] D. A. Sholihah and A. Mahmudi, "Keefektifan Experiential Learning Pembelajaran Matematika MTs Materi Bangun Ruang Sisi Datar," J. Ris. Pendidik. Mat., vol. 2, no. 2, pp. 175-185, 2015.

[4] Y. Purnomo, "Pengaruh Sikap Siswa Pada Pelajaran Matematika Prestasi

Cartesius: Jurnal Pendidikan Matematika Vol. 1, No. 1

CProdi Pendidikan Matematika Universitas Katolik Santo Thomas 
Belajar Matematika," JKPM, vol. 02, no. 01, pp. 93-105, 2016.

[5] P. M. Putri, "Pemahaman Konsep Matematika Pada Materi Turunan Melalui Pembelajaran Teknik Probing," J. Pendidik. Mat., vol. 1, no. 1, pp. 3-6, 2012.

[6] I. S. Pariska, S. Elniati, and Syafriandi, "Meningkatkan Kemampuan Pemahaman Konsep Siswa Kelas VIII SMP Negeri 2 Padang Pajang Melalui Pembelajaran Kooperatif Tipe Think Pair Share Disertai Peta Pikiran," J. Pendidik. Mat., vol. 1, no. 1, pp. 75-80, 2012.

[7] Rosdiati, "Upaya Meningkatkan Hasil Belajar Matematika Melalui Model Pembelajaran Kooperatif Tipe STAD Siswa Sekolah Dasar," Suara Guru J. Ilmu Pendidik. Sos. Sains, dan Hum., vol. 3, no. 2, pp. 315-321, 2017.

[8] PISA, "PISA 2012 Results in Focus," Program. Int. Student Assess., pp. 144, 2012.

[9] M. Afandi, C. Evi, and P. W. Oktarina, Model dan Metode Pembelajaran di Sekolah. 2013.

[10]H. Hasratuddin, "Pembelajaran Matematika Sekarang dan yang akan Datang Berbasis Karakter," J. Didakt. Mat., vol. 1, no. 2, pp. 30-42, 2014.

[11]A. Dina et al., "Implementasi Kurikulum 2013 Pada Perangkat Pembelajaran Model Discovery Learning Pendekatan Scientific Terhadap Kemampuan Komunikasi Matematis Materi Geometri Smk," Jkpm, vol. 2, no. 1, pp. 22-31, 2015.

[12]F. Haryanti and B. A. Saputro, "Pengembangan Modul Matematika Berbasis Discovery Learning Berbantuan Flipbook Maker Untuk Meningkatkan Kemampuan Pemahaman Konsep Pada Materi Segitiga," Kalamatika, vol. I, no. 2, pp. 147-161, 2016. 